\title{
HISTOLOGICAL AND ANTIMICROBIAL STUDY OF ONONIS ARVENSIS L.
}

\author{
Tünde Dénes, ${ }^{1}$ * SÁmuel Gergely Bartha, ${ }^{1}$ Mónika Kerényi, ${ }^{2}$ \\ Erzsébet Varga, ${ }^{3}$ Viktória Lilla Balázs, ${ }^{1}$ Rita Csepregi ${ }^{4}$ and Nóra Papp ${ }^{1}$ \\ ${ }^{1}$ Department of Pharmacognosy, University of Pécs, H-7624 Pécs, Hungary \\ ${ }^{2}$ Department of Medical Microbiology and Immunology, University of Pécs, H-7624 Pécs, Hungary \\ ${ }^{3}$ Department of Pharmacognosy and Phytotherapy, University of Medicine and Pharmacy, \\ 540139 Tîrgu Mureş, Romania \\ ${ }^{4}$ Department of Laboratory Medicine, University of Pécs, H-7624 Pécs, Hungary
}

(Received: January 10, 2017; accepted: May 4, 2017)

\begin{abstract}
In this study field restharrow (Ononis arvensis) was investigated for histological and antimicrobial features. The aerial part and the root were embedded in synthetic resin and investigated following sectioning by a rotation microtome. The antimicrobial activity and minimum inhibitory concentration of the solvent fractions of the aerial part were studied against four bacterial strains and one fungus. According to histology, the root covered by rhizodermis contains contiguous vascular elements, which are surrounded by sclerenchyma cells. The epidermis cells are anisodiametric in the stem, sepal, and petal. The bundles of the stem form a Ricinus type thickening. The adaxial side of the heterogeneous leaf is covered by unbranching non-glandular and capitate glandular trichomes. The stipule, petiole, sepals and petals are isolateral having mesomorphic stomata. Pollen grains are tricolpate. The different extracts of the herb showed antimicrobial activity against Escherichia coli, Pseudomonas aeruginosa, Salmonella Typhimurium, Staphylococcus aureus, and Candida albicans. Data show that the extracts of the leaf contain compounds which may be responsible for the antifungal effect, while extracts obtained from display against the tested bacteria, except Escherichia coli. Further studies are required to complete the phytochemical analysis and identify the antimicrobial compounds of extracts.
\end{abstract}

Keywords: Field restharrow - histology - antimicrobial activity - minimum inhibitory concentration bacteria - yeast

\section{INTRODUCTION}

The majority of recent medications derives originally from ancient herbal traditions. Medicinal plants with therapeutic value have been used for centuries. Numerous remedies, which have antifungal, antibacterial, and antiprotozoal activities, can be used systemically or locally both in human and veterinary medicine [17]. Plant based antimicrobials represent an outstanding undiscovered source for medicines because of their therapeutic potential. They are effective in the treatment of infectious diseases, and they simultaneously mitigate side effects, which are often associated with synthetic antimicrobials [18]. The exploration of these antimicrobials requires further analyses, which highlight, e.g. the importance of histological, phytochemical, and chemotaxonomical study of herbal drugs to identify their potential in the actual phytotherapy.

\footnotetext{
*Corresponding author; e-mail address: denestunde29@gmail.com
} 
Ononis genus (restharrows) is a large genus belonging to Fabaceae family. Many members of the genus were investigated for their phytochemical and pharmacological potential. Biochemical characterisation and identification of isoflavones and phenolic acids were described in $O$. spinosa L. [14, 19], more than 20 flavonoid aglycones in $O$. fruticosa L., O. natrix L., O. tridentate L. [38], and phenolic constituents in the root of $O$. vaginalis Vahl [1]. Isoflavones like ononin, and phytoestrogens, e.g. formonetin were identified in the root of Ononis angustissima L. [16]. Composition of the essential oil of Ononis viscosa L. subsp. breviflora (DC.) was identified by Erdemgil et al. [13]. Many Ononis species have been proven to have antibacterial, antifungal, antipyretic, and anti-inflammatory activities $[1-3,8,23]$. Decoctions from these plants have been reported to apply in gout, skin and rheumatic diseases [22]. The aqueous and ethanolic extracts of the aerial part of $O$. macrosperma Hub.-Mor. have remarkable wound healing and anti-inflammatory activities [31]. The styrylcoumarin derivatives of the root of $O$. vaginalis have shown antiviral activity against herpes simplex virus type 1 and weak cytotoxicity [1]. The dimethyl sulfoxide (DMSO) extracts of $O$. natrix $[2,24]$, and Ononis viscosa were assessed against some bacterial strains [12]. Ononis spinosa extracts have exhibited inhibitory effect similar to ofloxacin against Listeria monocytogenes (), L. ivanovii, L. innocua, and L. murrayi in agar diffusion and macrodilution assay [3], and also have antimicrobial activity against other Gram-positive and Gram-negative bacteria, and Candida species [4, 8, 23].

In our study field restharrow (Ononis arvensis L., syn.: Ononis hircine Jacq.) was selected for analyses based on a few earlier reports. The plant is a perennial shrub living in the humid fields of Europe. The $50-100 \mathrm{~cm}$ high erect stem is covered by trichomes. It has elliptical leaves and pink flowers [37]. The stem, leaf and root of the plant were studied for main histological features like multilayer tissues, cell wall thickening of vascular elements, crystals, stomata and trichome types [26]. In contrast to the commonly used root of $O$. spinosa, the aerial part of $O$. arvensis has been studied for essential oil [10], hydroxycinnamic acid [28], flavonoid [20, 27, 29, 33-36], isoflavon, triterpene (e.g. $\alpha$-onocerin), and coumarine (scopolin, scopoletin) content $[26,30]$.

To complete earlier anatomical description of the species [26], the aim of this study was to characterize the histological features of the root, stem, leaf, petiole, stipule, flower parts, and pollen. The goal was also to provide information on the antimicrobial effect of the extracts made of flowering stem and leaf against four bacterial strains and a yeast.

\section{MATERIAL AND METHODS}

\section{Data analysis and sample collection}

The analysis of data obtained from scientific databases (PubMed, Science Direct and Scopus) focused on the histological, phytochemical, antimicrobial, and pharmacological data of $O$. arvensis. Aerial part of the plant was harvested at a hayfield in 
Petreni, Homoród-valley in 2013, and at a road edge in Mereşti (Romania) in 2014. Herbarium specimens have been deposited and labelled with unique code at the Department of Pharmacognosy, University of Pécs, Hungary.

\section{Histological preparation}

The root, stem, leaf, petiole, stipule, and flower were fixed in a mixture of $96 \%$ ethanol : glycerine : distilled water $(1: 1: 1)$. Ethanol and glycerine were purchased from Molar Chemicals Ltd., Hungary. Dehydration followed in ethanol series (in 30, 50, 70 and $96 \%$ for $12,12,24$ and 3 hours, respectively), then plant materials were embedded in synthetic resin (Technovit 7100; Realtrade Ltd., Hungary). Cross sections $(10-15 \mu \mathrm{m})$ prepared by a rotation microtome (Anglia Scientific 0325) were stained in toluidine blue $(0.02 \%, 5 \mathrm{~min})$, placed consecutively into distilled water ( $5 \mathrm{sec}$, twice in 96\%), ethanol ( $3 \mathrm{~min}$ each), in isopropanol ( $2 \mathrm{~min}$ ), and twice in xylol (3 and $10 \mathrm{~min}$ ) [25]. Preparations were covered with Canada balsam purchased from Merck Ltd., Hungary.

The leaf and flower parts were studied by leaf surface cast method. Leaf samples were cut into $2 \times 2 \mathrm{~cm}$ pieces and boiled in $15 \mathrm{~mL}$ of distilled water $(10 \mathrm{~min}), 15 \mathrm{~mL}$ of the mixture of cc. potassium hydroxide and $10 \%$ ethanol (4 min), $4 \mathrm{~mL}$ of $5 \% \mathrm{H}_{2} \mathrm{O}_{2}$ $(1 \mathrm{~min})$, and there after they stayed at room temperature $(10 \mathrm{~min})$. Finally, they were boiled in $15 \mathrm{~mL}$ of $96 \%$ ethanol (10 $\mathrm{min})$ to lose their colour. Cleared samples were placed on slides and covered with Canada balsam. Petals and sepals (5 pieces each) were soaked into $20-30 \mathrm{~mL}$ of water and $10 \mathrm{~mL}$ of $80 \%$ chloral hydrate. Finally, 2-3 drops of glycerine were but onto the surface of the samples, and they were covered. Pollen grains were stained by fuchsin based on Beattie's work [6].

Leaves were studied by Nikon Eclipse 80i, while flower parts by IOR Bucharest ML-4M microscope, Olympus C01 stereo microscope, and Nicon Coolpix 4500 camera. Microphotos were taken by SPOT BASIC 4.0 program in each studied part.

\section{Preparation of extracts for microbiological study}

For microbiological analysis, the leaf and stem were grounded in a mortar $(1 \mathrm{~g}$ each $)$. Samples were suspended in $29 \mathrm{~mL}$ methanol in Erlenmeyer flasks and they were agitated at $150 \mathrm{rpm}$ for overnight. The extracts were filtered and evaporated at room temperature, then they were resuspended in $2 \mathrm{~mL}$ methanol. One $\mathrm{mL}$ of these extracts were mixed with $5 \mathrm{~mL}$ distilled water and $5 \mathrm{~mL}$ of $n$-hexane. After phase separation, $n$-hexane layers were collected and evaporated, and dry materials were measured. The aqueous phases were further extracted by the same method using chloroform, ethyl acetate, and butanol. Each extract was redissolved in $5 \mathrm{~mL}$ appropriate extraction solvents. This method was described previously by Lee et al. [21]. The whole method was carried out in triplicate and the final different dried residues were dis- 
solved in dimethyl sulfoxide (DMSO) (Sigma-Aldrich) to give the same concentration than in extraction solvents.

\section{Microbial strains and culture media}

The different extracts of plant stem and leaf were tested against Staphylococcus aureus (ATCC ${ }^{\circledR} 25923$ ), Escherichia coli (ATCC $\left.{ }^{\circledR} 25922\right)$, Pseudomonas aeruginosa (ATCC ${ }^{\circledR 27853), ~ S a l m o n e l l a ~ t y p h i m u r i u m ~(a b b r e v i a t e d ~ s c i e n t i f i c ~ n a m e ~ o f ~ S a l m o n e l l a ~}$ enterica subsp. enterica (Le Minor and Popoff) serovar. Typhimurium, ATCC ${ }^{\circledR} 14028$ ), and Candida albicans (ATCC ${ }^{\circledR}$ 90028). Standard Mueller-Hinton broth and agar without and with $0.3 \%$ Tween 20 were used as a bacterial culture media, as well as Sabouraud broth and agar without and with $0.3 \%$ Tween 20 were applied for cultivation of $C$. albicans strain.

\section{Tube dilution method for determination of minimum inhibitory concentration of plant extracts}

A $100 \mu \mathrm{L}$ of each extract in appropiate extraction solvent were given to $1900 \mu \mathrm{L}$ of Mueller-Hinton broth with $0.3 \%$ Tween 20, and twofold dilutions were performed in $1 \mathrm{~mL}$ of culture medium containing tubes. Mueller-Hinton broth alone was used for dilution of water extracts.

Each inoculum was standardised to MacFarland $0.5\left(\sim 1.5 \times 10^{8}\right.$ colony forming unit $=\mathrm{CFU} / \mathrm{mL}$ ) by spectrophotometer (Novospec ${ }^{\mathrm{TM}}$ Plus Amersham Biosciences), and each tube was inoculated. After inoculation they contained approximately $5 \times 10^{5}$ $\mathrm{CFU} / \mathrm{mL}[9]$.

Following overnight incubation at $37^{\circ} \mathrm{C}$, each tube was examined for visible turbidity that means bacterial growth. Subcultures were performed from unturbid tubes checking the bactericidal and/or bacteriostatic effects of extracts on Mueller-Hinton agar medium. The growth of colonies was checked on the medium after incubation for $24 \mathrm{~h}$ at $37^{\circ} \mathrm{C}$. The same method was applied in the investigation of extracts' effect for growth of Candida albicans in Sabouraud medium. Antimicrobial activity of solvent dilutions was also checked and their results were compared with the extracts' dilutions. Minimum inhibitory concentration (MIC) values were determined both in leaf and stem extracts. The study was carried out in triplicate.

\section{Microdilution method for determination of minimum inhibitory concentration of plant extracts}

Same concentration of each extract in 2\% DMSO than in extraction solvents was applied and diluted by twofold dilution in Mueller-Hinton broth on 96 wells microplates and was inoculated by microorganisms similarly to tubes, so that final concen- 
trations in microwells were less than $1 \%$ DMSO, which has no effect on bacterial growth. A $1 \%$ DMSO was used as control and was inoculated. Following overnight incubation each inoculated well was checked for turbidity. Each extract's dilution was checked triplicate for each strain.

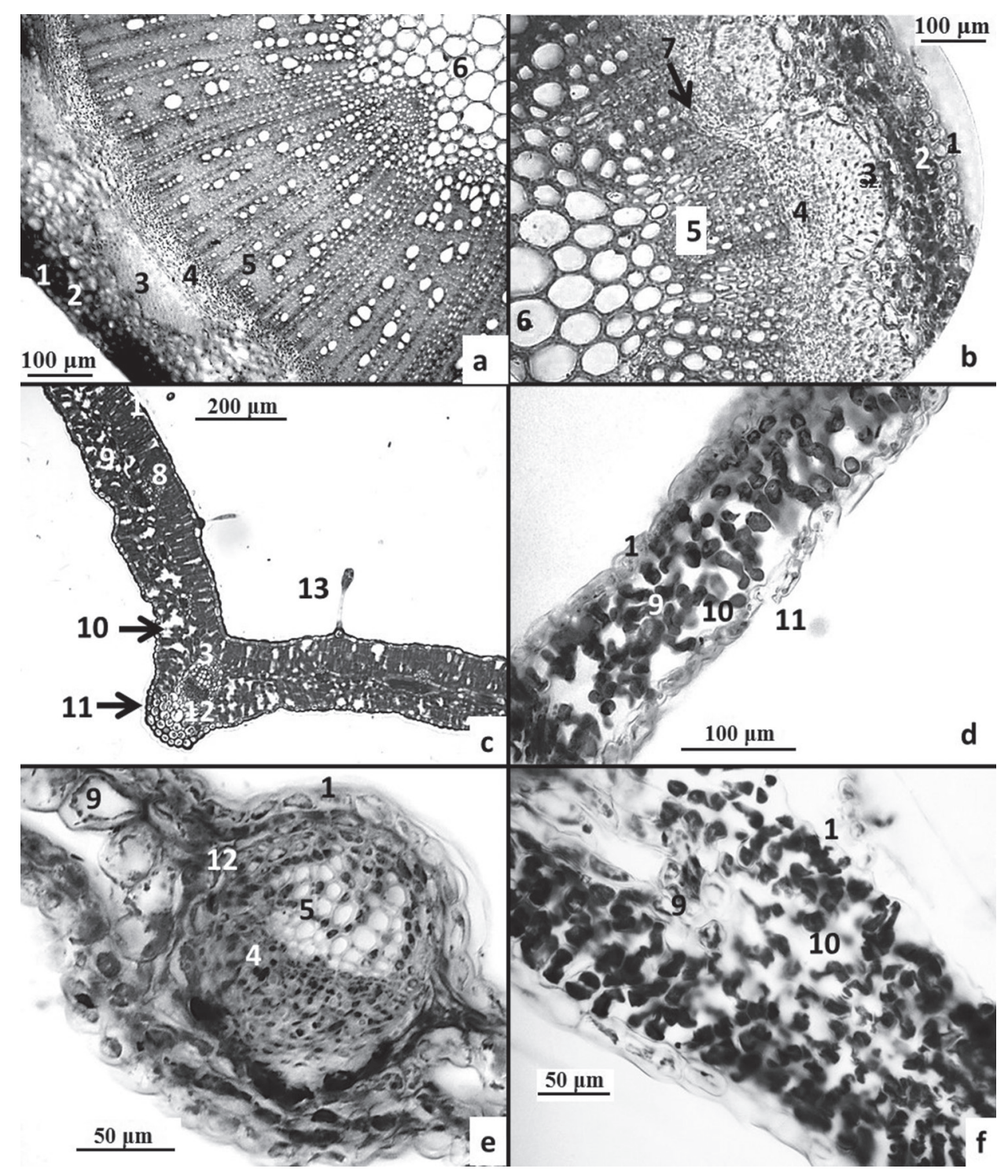

Fig. 1. Histological features of the vegetative parts of Ononis arvensis. (a) root, (b), stem, (c) leaf, (d) stipule, (e-f) petiole. In each photo: 1. epidermis, 2. lamellar collenchyma, 3. sclerenchyma, 4. phloem, 5. xylem, 6. parenchyma, 7. cambium, 8. palisade parenchyma, 9. spongy parenchyma, 10. intercellular space, 11. mesomorphic stomata, 12. collateral closed bundle, 13. capitate glandular trichome 


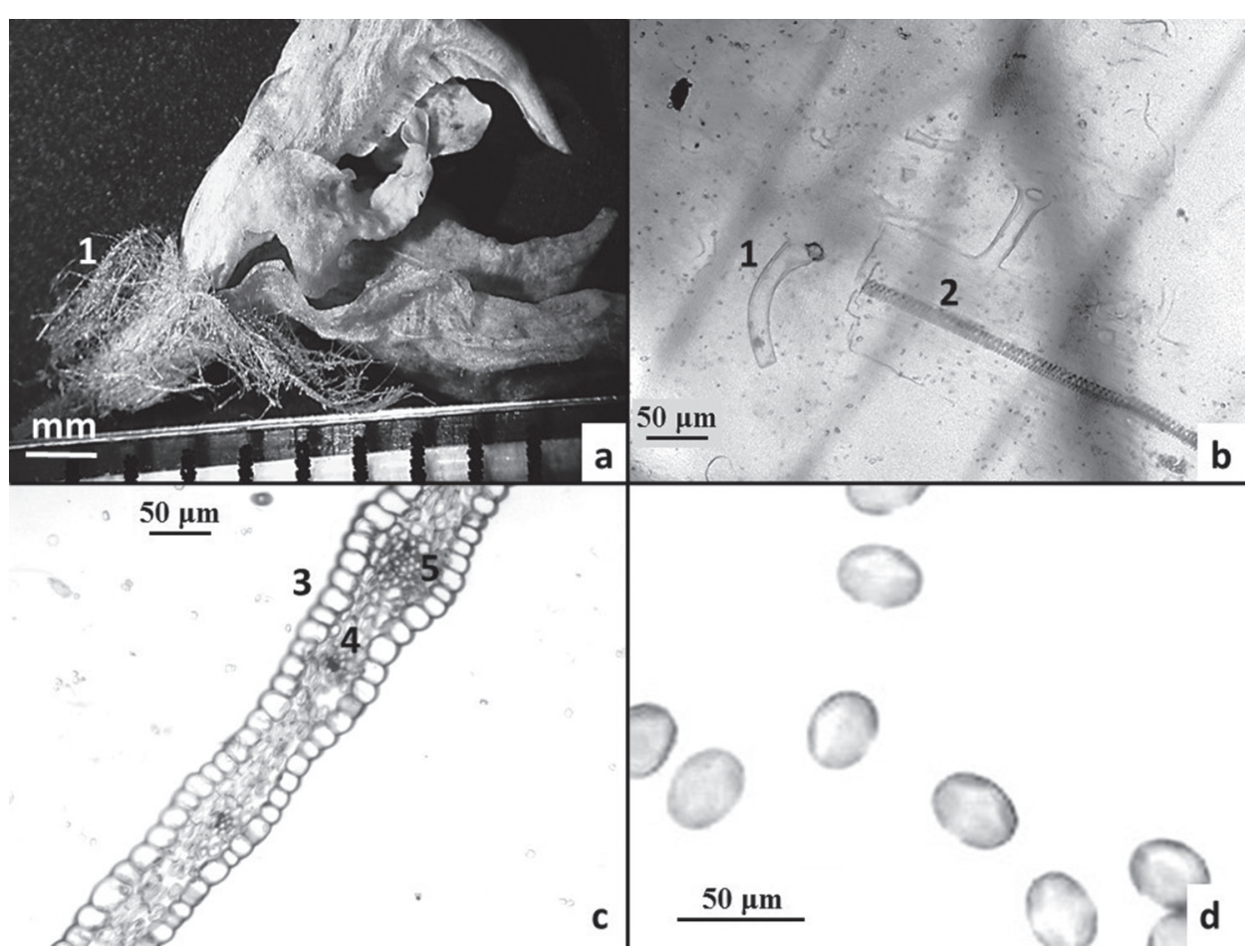

Fig. 2. Histological features of generative parts of Ononis arvensis. (a) flower (by stereo microscope), (b) cleared sepal, (c) petal, (d) tricolpate pollen grains. In each photo: 1. non-glandular trichomes, 2. spiral wall thickening of tracheas, 3. epidermis, 4. spongy parenchyma, 5. collateral closed bundle

Table 1

Fraction concentration of Ononis arvensis leaf extracts after evaporation redissolved in solvent and applied for dilution and determination of MIC value

\begin{tabular}{|l|c|c|c|c|}
\hline \multicolumn{1}{|c|}{ Solvents } & $\begin{array}{c}\text { Weight of extract after } \\
\text { evaporation }(\mathrm{mg})\end{array}$ & $\begin{array}{c}\text { Concentration after } \\
\text { redissolved in } 5 \mathrm{~mL} \\
\text { solvent }(\mathrm{mg} / \mathrm{mL})\end{array}$ & $\begin{array}{c}\text { Weight in } 100 \mu \mathrm{L} \\
\text { solvent }(\mu \mathrm{g})\end{array}$ & $\begin{array}{c}\text { Started concentration } \\
\text { for dilution }(\mu \mathrm{g} / \mathrm{mL})\end{array}$ \\
\hline Methanol & 185.6 & 18.56 & 1856 & 928 \\
\hline Hexane & 0.8 & 0.16 & 16 & 8 \\
\hline Chloroform & 10.2 & 2.04 & 204 & 102 \\
\hline Ethyl acetate & 7.4 & 1.48 & 148 & 74 \\
\hline Butanol & 59.5 & 11.9 & 1190 & 595 \\
\hline Water & 21.5 & 4.3 & 430 & 215 \\
\hline
\end{tabular}




\section{RESULTS}

\section{Histological features}

A lamellar collenchyma consisting of 3-4 cell layers was observed under the rhizodermis in the root (Fig. 1a). The vascular elements surrounded by sclerenchyma cells form a contiguous ring with medullary rays in the xylem. Isodiametric parenchyma cells can be found in the centre.

In the stem, the cells of single-layered epidermis are anisodiametric (height/width falls within the range of 1.5-3.0) (Fig. 1b). The flattened cells of lamellar collenchyma form a cortex under the epidermis. Sclerenchyma cells extend in half moonshaped form on the upper part of collateral open bundles, which arrange in concentric circles. Medullary rays are found between the vascular bundles, while the central part consists of several loosely arranged parenchyma cells forming the pith. The thickening type of the stem can be classified into Ricinus type involving the intra- and interfascicular cambium, which produce concentric vascular elements not only in, but among the bundles, as well.

The adaxial surface of the leaf is covered by unbranching non-glandular and capitate glandular trichomes with 3 cells in the neck. Both the adaxial and abaxial surfaces are covered by a thin cuticle layer. The epidermis is single-layered consisting of flattened cells. The leaf structure is dorsiventral (bifacial). The heterogeneous mesophyll includes palisade (2 layers) and isodiametric spongy cells (4-6 layers), and several intercellular spaces (Fig. 1c). The collateral closed bundles are surrounded by sclerenchyma cells which form a protective sheath. Mesomorphic stomata are found on the abaxial side (hypostomatic leaf).

Stipules were observed at the base of the leaves surrounding the stem. The epidermis is one-cell-layered on both sides. The mesophyll consists of only spongy cells (isolateral structure) with intercellular spaces. Similar to the leaves, stomata are in mesomorphic position on the abaxial side (Fig. 1d).

The petiole is surrounded by a single-layered epidermis on both sides (Fig. 1e-f). In the mesophyll, collateral closed bundle is surrounded by isodiametric parenchyma cells and intercellulars (Fig. 1e), which also extend to the terminal parts of the petiole (Fig. 1f).

In the flower, sepals are covered by unicellular non-glandular hairs called bristles (Fig. 2a-b). The stomata are mesomorphic. The tracheas can be characterized by spiral cell wall thickening both in sepals and petals. The epidermis cells of petals are anisodiametric forming a single layer on both sides. The middle part is composed of 4-5 layers of isodiametric parenchyma cells (isolateral structure) and collateral closed bundles (Fig. 2c). The opolar and prolate pollen grains are 20-25 $\mu \mathrm{m}$ of diameter. The 3 apertures are combined including both colpus and porus (tricolpate aperture) (Fig. 2d). 
Table 2

Minimum inhibitory concentration of leaf extract fractions $(\mu \mathrm{g} / \mathrm{mL})$ with solvents

\begin{tabular}{|c|c|c|c|c|c|}
\hline Solvents & Escherichia coli & $\begin{array}{c}\text { Pseudomonas } \\
\text { aeruginosa }\end{array}$ & $\begin{array}{c}\text { Staphylococcus } \\
\text { aureus }\end{array}$ & $\begin{array}{l}\text { Salmonella } \\
\text { typhimurium }\end{array}$ & Candida albicans \\
\hline $\begin{array}{l}\text { Methanol } \\
2 \% \text { DMSO }\end{array}$ & $\begin{array}{l}928< \\
(5 \%) \\
928<\end{array}$ & $\begin{array}{l}928< \\
(5 \%) \\
928<\end{array}$ & $\begin{array}{l}928< \\
(5 \%) \\
928<\end{array}$ & $\begin{array}{l}928< \\
(5 \%) \\
928<\end{array}$ & $\begin{array}{l}928< \\
(5 \%) \\
928<\end{array}$ \\
\hline $\begin{array}{l}\text { Hexane } \\
2 \% \text { DMSO }\end{array}$ & $\begin{array}{c}8< \\
(5 \%) \\
8<\end{array}$ & $\begin{array}{c}8< \\
(5 \%) \\
8<\end{array}$ & $\begin{array}{c}8< \\
(5 \%) \\
8<\end{array}$ & $\begin{array}{c}8< \\
(5 \%) \\
8<\end{array}$ & $\begin{array}{c}8 * \\
(5 \%) \\
8<\end{array}$ \\
\hline $\begin{array}{l}\text { Chloroform } \\
2 \% \text { DMSO }\end{array}$ & $\begin{array}{c}\mathbf{5 1 *} \\
(2.5 \%) \\
102<\end{array}$ & $\begin{array}{l}102 \leq \\
(5 \%) \\
102<\end{array}$ & $\begin{array}{l}102 \leq \\
(5 \%) \\
102<\end{array}$ & $\begin{array}{c}51 \leq \\
(2.5 \%) \\
102<\end{array}$ & $\begin{array}{c}\mathbf{1 2 . 7 5} \% \\
(0.625 \%) \\
102<\end{array}$ \\
\hline $\begin{array}{l}\text { Ethyl acetate } \\
2 \% \text { DMSO }\end{array}$ & $\begin{array}{c}74 \leq \\
(5 \%) \\
74<\end{array}$ & $\begin{array}{c}74 \leq \\
(5 \%) \\
74<\end{array}$ & $\begin{array}{c}74 * \\
(5 \%) \\
74<\end{array}$ & $\begin{array}{c}74 \leq \\
(5 \%) \\
74<\end{array}$ & $\begin{array}{c}37 * \\
(2.5 \%) \\
74<\end{array}$ \\
\hline $\begin{array}{l}\text { Butanol } \\
2 \% \text { DMSO }\end{array}$ & $\begin{array}{l}595 \leq \\
(5 \%) \\
595<\end{array}$ & $\begin{array}{c}148 \leq \\
(1.25 \%) \\
595<\end{array}$ & $\begin{array}{l}595 \leq \\
(5 \%) \\
595<\end{array}$ & $\begin{array}{l}595 \leq \\
(5 \%) \\
595<\end{array}$ & $\begin{array}{c}287 \leq \\
(2.5 \%) \\
595<\end{array}$ \\
\hline Water & $215<$ & $215<$ & $215<$ & $215<$ & $215<$ \\
\hline
\end{tabular}

*Antimicrobial effect of extract; ( ): extraction solvent concentration.

$\leq$ Effects of concentration of diluted control solvent and that of the extract in the same concentration of solvent are equal (started concentrations of solvents were $5 \%$ in each extract and solvent control dilution).

$<$ No antimicrobial effect of extract in this concentration.

Table 3

Fractions concentration of Ononis arvensis stem extracts after evaporation redissolved in solvent and applied for dilution and determination of MIC value

\begin{tabular}{|l|c|c|c|c|}
\hline \multicolumn{1}{|c|}{ Solvents } & $\begin{array}{c}\text { Weight of extract } \\
\text { after evaporation } \\
(\mathrm{mg})\end{array}$ & $\begin{array}{c}\text { Concentration after } \\
\text { redissolved in } 5 \mathrm{~mL} \\
\text { solvent }(\mathrm{mg} / \mathrm{mL})\end{array}$ & $\begin{array}{c}\text { Weight in } 100 \mu \mathrm{L} \\
\text { solvent }(\mu \mathrm{g})\end{array}$ & $\begin{array}{c}\text { Started concentration } \\
\text { for dilution }(\mu \mathrm{g} / \mathrm{mL})\end{array}$ \\
\hline Methanol & 91.6 & 9.16 & 916 & 458 \\
\hline Hexane & 0.6 & 0.12 & 17 & 6 \\
\hline Chloroform & 8.7 & 1.74 & 32 & 87 \\
\hline Ethyl acetate & 1.6 & 0.32 & 186 & 93 \\
\hline Butanol & 9.3 & 1.86 & 196 & 98 \\
\hline Water & 9.8 & 1.96 & & 16 \\
\hline
\end{tabular}

\section{Minimum inhibitory concentration of plant extracts}

The quantities of dry residues were different after evaporation (Tables 1, 3). Each extract was redissolved in $5 \mathrm{~mL}$ extraction solvents and in appropriate volume of DMSO to use as stock solutions for MIC determination. The stock solutions concen- 
trations of the same extracts were equal, but the concentrations of different extracts' stock solution were not the same.

The chloroform extract of the leaf with extraction solvent showed strong inhibitory effect against Escherichia coli and Candida albicans (MIC values were $51 \mu \mathrm{g}$ / $\mathrm{mL}$ and $12.75 \mu \mathrm{g} / \mathrm{mL}$, respectively). Leaf hexane extract was effective only against Candida albicans (MIC value $8 \mu \mathrm{g} / \mathrm{mL}$ ), whereas ethyl acetate extract inhibited growth of Staphylococcus aureus and C. albicans in $74 \mu \mathrm{g} / \mathrm{mL}$ and $37 \mu \mathrm{g} / \mathrm{mL}$ concentration (Table 2). Ethyl acetate extract of the stem was effective against $S$. aureus and C. albicans in low concentrations (MIC 16 and $8 \mu \mathrm{g} / \mathrm{mL}$ ). Chloroform stem extract with $43.5 \mu \mathrm{g} / \mathrm{mL}$ had impact only on the growth of Pseudomonas aeruginosa. Almost the same concentration $(46.5 \mu \mathrm{g} / \mathrm{mL})$ of butanol extract had inhibitory effect on growth of Salmonella typhimurium (Table 3). Minimum inhibitory concentrations of these extracts were higher against the investigated microorganism (Tables 2, 4) than that of any other effective antibiotics or antifungal agents, which have MIC values between 0.03 and $8 \mu \mathrm{g} / \mathrm{mL}$. We failed to detect any antimicrobial effect with methanolic and aqueous plant extracts, or with the hexane stem extract with extraction solvent, or with any extracts in DMSO. Other extracts of the plant showed similar antimicrobial activity to the diluted extraction solvents in the same concentration.

Table 4

Minimum inhibitory concentrations of stem extract fractions $(\mu \mathrm{g} / \mathrm{mL})$ with solvents

\begin{tabular}{|l|c|c|c|c|c|}
\hline \multicolumn{1}{|c|}{ Solvents } & Escherichia coli & $\begin{array}{c}\text { Pseudomonas } \\
\text { aeruginosa }\end{array}$ & $\begin{array}{c}\text { Staphylococcus } \\
\text { aureus }\end{array}$ & $\begin{array}{c}\text { Salmonella } \\
\text { typhimurium }\end{array}$ & Candida albicans \\
\hline Methanol & $458<$ & $458 \leq$ & $458<$ & $458<$ & $458<$ \\
$2 \%$ DMSO & $(5 \%)$ & $(5 \%)$ & $(5 \%)$ & $(5 \%)$ & $(5 \%)$ \\
\hline Hexane & 458 & $458<$ & $458<$ & $458<$ & $458<$ \\
$2 \%$ DMSO & $6<$ & $6<$ & $6<$ & $6<$ & $6<$ \\
\hline & $6<$ & $(5 \%)$ & $(5 \%)$ & $(5 \%)$ & $(5 \%)$ \\
Chloroform & $87 \leq$ & $43.5 *$ & $43.5 \leq$ & $8<$ & $6<$ \\
$2 \%$ DMSO & $(5 \%)$ & $(2.5 \%)$ & $(2.5 \%)$ & $(5 \%)$ & $43.5 \leq$ \\
\hline & $87<$ & $87<$ & $87<$ & $87<$ & $87<$ \\
Ethyl acetate & $16 \leq$ & $16 \leq$ & $16 *$ & $16 \leq$ & $8 \%$ \\
$2 \%$ DMSO & $16<$ & $(5 \%)$ & $(5 \%)$ & $(5 \%)$ & $(2.5 \%)$ \\
\hline & $93 \leq$ & $23.25 \leq$ & $93 \leq$ & $46.5 *$ & $46<$ \\
Butanol & $(5 \%)$ & $(1.25 \%)$ & $(5 \%)$ & $(2.5 \%)$ & $(2.5 \%)$ \\
$2 \%$ DMSO & $93<$ & $93<$ & $93<$ & $93<$ & $93<$ \\
\hline Water & $98<$ & $98<$ & $98<$ & $98<$ & $98<$ \\
\hline
\end{tabular}

*Antimicrobial effect of extract; ( ): extraction solvent concentration.

$\leq$ Effects of concentration of diluted control solvent and that of the extract in the same concentration of solvent are equal (started concentrations of solvents were $5 \%$ in each extract and solvent control dilution).

$<$ No antimicrobial effect of extract in this concentration. 


\section{DISCUSSION}

The observed histological features of the root of field restharrow are now fully described for the first time involving collenchyma and sclerenchyma, completing the anatomical data reported earlier [26]. In the stem, Ricinus type thickening and sclerenchyma cells were observed as new data besides flattened cells of lamellar collenchyma documented earlier [26].

Based on previous reports [11], non-glandular and capitate glandular trichomes were also found on the adaxial surface of the leaf, which we complemented with 3 cells in the neck of the trichomes. The heterogeneous mesophyll of dorsiventral leaf $[11,26]$ is composed of palisade and spongy cells, and collateral closed bundles encompassed by sclerenchyma cells [26]. Stipules, which are characteristic for to Fabaceae family [37], can be found at the base of the leaves. Histological structure of the petiole, the sepals and petals involving cell shape of epidermis, bundle, stomata and trichome types, as well as pollen characteristics were documented for the first time.

The antimicrobial activities of Ononis species have been reported in many studies $[1-3,5,7,8,23,24]$. In our study, antibacterial effects were detected in all stem and leaf extracts compared to extraction solvents' effect in the same concentration. Antimicrobial effects of these extracts were noticed against Staphylococcus aureus, Escherichia coli, Pseudomonas aeruginosa, and Salmonella typhimurium at the first time. It was surprising that the extracts dissolved in DMSO did not show any antimicrobial activity in the same concentrations, which have inhibition for bacterial growth. The low concentrations can explain that ineffectivity. Certain extracts of $O$. arvensis in low concentration can evoke or increase the antimicrobial activities of low concentration extraction solvents.

Our results were compared with data of other Ononis species, mainly the more frequently investigated $O$. spinosa, which also inhibited the growth of $S$. aureus, E. coli, P. aeruginosa, and Bacillus subtilis [8]. Certain leaf and stem extracts of $O$. arvensis have shown antifungal activity in low concentration against Candida albicans similar to the aqueous and ethanolic extracts of $O$. spinosa $(\mathrm{MIC}=1.25 \mu \mathrm{g} /$ $\mathrm{mL}$ ) $[4,23]$, which were also effective against C. glabrata (only ethanol extract, $\mathrm{MIC}=5.00 \mu \mathrm{g} / \mathrm{mL}$ ) and $C$. krusei, but were not effective against other clinical Candida species [4, 8, 23]. The ethyl acetate extract of Ononis natrix inhibited the growth of Bacillus subtilis and B. brevis (MIC 12.5-50 $\mu \mathrm{g} \cdot \mathrm{mL}^{-1}$ ) [5], while ethanol, hexane, acetone and methanol extracts were described to have small inhibitory activity against $S$. aureus, Staphylococcus epidermidis, S. saprophiticus similar to $O$. arvensis, but they were ineffective against E. coli, E. faecalis, Shigella flexneri, Enterobacter cloaceae, Klebsiella pneumonia, Aeromonas hydrophila, and Serratia marcescens, as well as for $P$. aeruginosa, which was more resistant to antimicrobial agents $[2,7]$. The ethanolic extracts of $O$. hirta and $O$. sicula have potential antimicrobial activity (in more than $1000 \mu \mathrm{g} / \mathrm{mL}$ concentration) against MRSA, Bacillus cereus, E. coli, P. aeruginosa, S. typhimurium, C. albicans, and Aspergillus niger. The $n$-hexane extract of $O$. hirta aerial parts showed stronger activity against $P$. aerugi- 
nosa (MIC of $125 \mu \mathrm{g} / \mathrm{mL}$ ) [32]. In addition to plant extracts, the essential oil of $O$. angustissima L. exerted significant antibacterial effect against Enterococcus faecalis $(\mathrm{MIC}=0.07 \mathrm{mg} / \mathrm{mL}$ ) and $P$. aeruginosa $(\mathrm{MIC}=0.31 \mathrm{mg} / \mathrm{mL})[15]$.

In the present study the histological and antimicrobial results provide new data for the possible medicinal use of Ononis arvensis. However, the minimum inhibitory concentrations of plant extracts with small amount of extraction solvents were higher than the MIC values of antibiotics, which are applied for treatment of infections, they showed strong antimicrobial activity against the tested microorganisms. Despite the effective extracts contain small concentration of extraction solvents they can be applied with these in the topical treatment of superficial infection if their cytotoxicity is checked in human tissue culture. It is known the phenol is harmless and cytotoxic, but in small concentration (1.4\%) is used in topical treatment. Determining the exact chemical compounds or components of the extracts, which have antimicrobial effect requires further investigation with more advanced techniques and other microorganisms. The isolated components without toxic solvents might have on effect against bacterial and fungal pathogens in very low concentration, similarly to antibiotics.

In conclusion, our results emphasize the promising degree of antimicrobial activity of Ononis arvensis against the tested microorganisms. Therefore these preliminary data should be supported by further large-scale studies in the future.

\section{ACKNOWLEDGEMENTS}

We are grateful for the contributions of the informants in the fieldwork, and for Dragica Purger and Tünde Svoboda for their help in the study. This work was supported by a grant from the OTKA (Hungarian Scientific Research Fund, PD 108534).

\section{REFERENCES}

1. Abdel-Kader, M. S. (2001) Phenolic constituents of Ononis vaginalis roots. Planta Medica 67, 388390.

2. Al-Bakri, A. G., Afifi, F. U. (2007) Evaluation of antimicrobial activity of selected plant extracts by rapid XTT colorimetry and bacterial enumeration. J. Microbiol. Meth. 68, 19-25.

3. Altanlar, N., Citoglu, G. S., Y1lmaz, B. S. (2006) Antilisterial activity of some plants used in folk medicine. Pharm. Biol. 44, 91-94.

4. Altuner, E. M., Ceter, T., Işlek, C. (2010) Investigation of antifungal activity of Ononis spinosa L. ash used for the therapy of skin infections as folk remedies. Mikrobiyol Bul. 44, 633-639.

5. Al-Zereini, W. A. (2017) Ononis natrix and Salvia verbenaca: Two Jordanian medicinal plants with cytotoxic and antibacterial activities. J. Herbs Spices Med. Plants 23, 1-8.

6. Beattie, A. J. (1971) A technique for the study of insect-borne pollen. Pan-Pac Entomol. 47, 82.

7. Ben Sassi, A., Barzallah-Skhiri, F., Aouni, M. (2007) Investigation of some medicinal plants from Tunisia for antimicrobial activities. Pharm. Biol. 15, 421-428.

8. Citoglu, G. S., Altanlar, N. (2003) Antimicrobial activity of some plants used in folk medicine. J. Fac. Pharm. 32, 159-163.

9. CLSI (2012) Methods for dilution antimicrobial susceptibility tests for bacteria that grow aerobically; approved standard, 9th ed. In: CLSI document M07-A9. Wayne: Clinical and Laboratory Standards Institute, pp. 12-13. 
10. Dedio, I., Kozlowski, J. (1977) Comparative morphological and phytochemical studies of Ononis spinosa L. and Ononis arvensis L. Acta Pol Pharm. 34, 103-108.

11. Dénes, T., Papp, N., Varga, E. (2014) Some histological features of Ononis arvensis (Az Ononis arvensis L. hisztológiai jellemzői). In Abstracts of the 15 ${ }^{\text {th }}$ Congressus Pharmaceuticus Hungaricus, Budapest, 10-12 April 2014, Gyógyszerészet Suppl. 84.

12. Diaz, R. M., Quevedo-Sarmiento, J., Ramos-Cormenzana, A., Cabo, P., Cabo, J. (1989) Phytochemical and antibacterial screening of some species of Spanish Asteraceae. Part II. Fitoterapia 60, 353-355.

13. Erdemgil, F. Z., Kurkcuoglu, M., Baser, K. H. C. (2002) Composition of the essential oil of Ononis viscosa subsp. breviflora. Chem. Nat. Compd. 38, 565-567.

14. Gampe, N., Darcsi, A., Lohner, S., Béni, S., Kursinszki, L. (2016) Characterization and identification of isoflavonoid glycosides in the root of spiny restharrow (Ononis spinosa L.) by HPLC-QTOFMS,HPLC-MS/MS and NMR. J. Pharm. Biomed. Anal. 123, 74-81.

15. Ghribi, L., Nejma, A. B. (2016) Chemical composition, cytotoxic and antibacterial activities of the essential oil from the Tunisian Ononis angustissima L. (Fabaceae). J. Oleo Sci. 65, 339-345.

16. Ghribi, L., Waffo-Téguo, P., Cluzet, S., Marchal, A., Marques, J., Mérillon, J. M., Jannet, H. B. (2015) Isolation and structure elucidation of bioactive compounds from the roots of the Tunisian Ononis angustissima L. Bioorg. Med. Chem. Lett. 25, 3825-3830.

17. Heinrich, M., Barnes, J., Gibbons, S., Williamson, E. M. (2004) Fundamentals of Pharmacognosy and Phytotherapy. Churchill Livingstone, Edinburgh, pp. 4-7.

18. Iwu, M. W., Duncan, A. R., Okunji, C. O. (1999) New antimicrobials of plant origin. In: Janick, J. (ed.), Perspectives on New Crops and New Uses. ASHS Press, Alexandria, VA, pp. 457-462.

19. Klejdus, B., Vacek, J., Lojková, L., Benesová, L., Kubán, V. (2008) Ultrahigh-pressure liquid chromatography of isoflavones and phenolic acids on different stationary phases. J. Chromatogr. A. 1195, 52-59.

20. Kovalev, V. N., Borisov, M. I., Spiridonov, V. N. (1976) Phenolic compounds of Ononis arvensis Chem. Nat. Compd. 10, 820-821.

21. Lee, J. H., Cho, S., Paik, H. D. (2014) Investigation on antibacterial and antioxidant activities, phenolic and flavonoid contents of some Thai edible plants as an alternative for antibiotics. Asian Australas J. Anim. Sci. 27, 1461-1468.

22. Liebezeit, G. (2008) Ethnobotany and phytochemistry of plants dominant in salt marshes of the Lower Saxonian Wadden Sea, southern North Sea. Senck Marit. 38, 1-30.

23. Mahasneh, A. M., El-Oqlah, A. A. (1999) Antimicrobial activity of extracts of herbal plants used in the traditional medicine of Jordan. J. Ethnopharmacol. 64, 271-276.

24. Maruhenda, R., Gimenez, E. (1986) The solubility of the antibacterial principles of Ononis natrix L. Boll. Chim. Farm. 125, 21-23. (in Spanish)

25. Sárkány, S., Szalai, I. (1957) Practical Botany. Tankönyvkiadó, Budapest, pp. 568-575. (in Hungarian)

26. Sichinava, M., Mchedlidze, K., Churadze, M., Alania, M., Aneli, D. J. (2014) Chemical composition and microstructural peculiarities of overground and underground vegetative organs of field restharrow (Ononis arvensis L.). Georgian Med. News 231, 88-94.

27. Spilková, J. (1990) Flavonoids of Ononis arvensis L. Dissertation. Faculty of Pharmacy, Charles University, Hradec Králové, pp. 1-39.

28. Spilková, J., Bednár, P., Stroblíková, R. (2001) Capillary electrophoretic analysis of hydroxy-cinnamic acids from Ononis arvensis L. Pharmazie 56, 424-425.

29. Spilková, J., Hubík, J. (1982) Pharmacognosy study of Ononis arvensis L.II. Flavonoids and onocerin in the drug. Cesk Farm. 31, 24-26. (in Czech)

30. Spilková, J., Pilkova, J., Dusek, J., Solich, P., Stranska, J., Ruzickova, K. (1996) Application of 2-dimensional chromatography for determination of ononin in the roots and aerial parts of Ononis arvensis L. J. Planar Chromat. 4, 299-302.

31. Süntar, I., Baldemir, A., Coşkun, M., Keleş, H., Küpeli Akkol, E. (2011) Wound healing acceleration effect of endemic Ononis species growing in Turkey. J. Ethnopharmacol. 135, 63-70. 
32. Talib, W. H., Mahasneh, A. M. (2010) Antimicrobial, cytotoxicity and phytochemical screening of Jordanian plants used in traditional medicine. Molecules 15, 1811-1824.

33. Tumova, L. (1999) The effect of elicitors from Pseudomonas aeruginosa on the production of flavonoids in cultures of Ononis arvensis L. Cesk Farm. 48, 262-264. (in Czech)

34. Tumova, L., Brancuzká, R., Tuma, J. (2001) The effect of salicylic acid on flavonoid production of Ononis arvensis tissue culture. Farmacevtski Vestnik 52, 327-329. (in Czech)

35. Tumova, L., Tuma, J., Dolezal, M. (2011) Pyrazinecarboxamides as potential elicitors of flavonolignan and flavonoid production in Silybum marianum and Ononis arvensis cultures in vitro. Molecules $16,9142-9152$.

36. Tumova, L., Zápalková, L. (2002) Effect of jasminic acid on production of flavonoids in a culture of Ononis arvensis L. in vitro. Cesk Farm. 51, 96-98. (in Czech)

37. Tutin, T. G., Heywood, V. H., Burges, N. A., Moore, D. M., Valentine, D. H., Walters, S. M., Webb, D. A. (2010) Flora Europaea. Vol. 2, Cambridge University Press, Cambridge. p. 147.

38. Wollenweber, E., Dorr, M., Rivera, D., Roitman, J. N. (2003) Externally accumulated flavonoids in three Mediterranean ononis species. Z. Naturforsch. 58, 771-775. 